\title{
The future of good Samaritan legislation related to the legacy of hardrock mining in the United States and the challenges it poses for our social license to operate
}

\author{
JS Collyard SLR International, USA
}

T Patterson SLR International, USA

\begin{abstract}
The social licence to operate is one of, if not the greatest challenge and risk faced when expanding or opening a new mine. Why is that? The negative public legacy of mining in the United States, and globally for that matter, is one of human health impact and environmental destruction. This legacy is the result of short-term vision, a lack of concern for impacts to the natural environment and human health, and a lack of adequate regulatory guidance and enforcement. Fortunately, the mining industry is committing to long-term planning and operation practices for preserving and protecting environmental and human health, and committing to good land and water stewardship through investing in an ever-evolving set of technical capabilities to execute these reformed mining legacy outcomes.
\end{abstract}

Good Samaritan legislation in the United States, and perhaps globally, may present the industries greatest opportunity to change the legacy of mining, its public image, and ultimately improve the mining industry's ability to obtain social licence to operate. However, this enabling legislation, as it applies to abandoned mine land legacy issues, does not exist for federal and state environmental protection programmes and the political attempts over the past two decades to establish it have not been successful.

This paper and presentation describe the status of abandoned mine land risks and concerns, the current regulatory agencies and structure, and processes applicable to mining and mine reclamation. The history, current state, and potential future benefits of Good Samaritan abandoned mine reclamation legislation / regulations at the federal and state level in the United States is the focus of this paper and presentation.

Good Samaritan legislation presents opportunities and risks for the mining community and a pathway to better allocate private and public funds to improve the negative legacy of the mining industry and earn social licences to continue to operate mines in the United States. Stakeholders involved directly or indirectly in the mining community have the opportunity now to shape legislation and the abandoned mine land reclamation approach to achieve their goals. We as miners have the opportunity to shape our legacy, to make positive changes to the environment, to benefit stakeholders, and to reduce the risk and challenge of obtaining social licence to operate and as a result continue to provide the world with resources through adequate Good Samaritan legislation.

Keywords: legacy mine sites, abandoned mine lands, orphan mine sites, good Samaritan, clean water act, USEPA, CERCLA, USFS, BLM, USGS, social license to operate, stakeholder engagement, mining legacy

\section{Introduction}

The negative public legacy of mining in the United States, and globally, is one of historical human health impacts and environmental destruction and has a significant ongoing effect on the mining industries' social licence to operate. This legacy is the result of short-term vision, a lack of concern for impacts to the natural environment and human health, and a lack of adequate regulatory guidance and enforcement prior to the late 1970s. Fortunately, the mining industry is committing to long-term planning, committing to preserving and protecting environmental and human health, committing to good land and water stewardship practises, 
committing to working with regulatory agencies to develop guidance and regulations that are protective and feasible, and possess an ever-evolving set of technical capabilities to realise the industries' commitments.

The social licence to operate is one of, if not the greatest risk facing the mining industry today and the legacy of mining plays a significant role in obtaining that licence. Abandoned Mine Lands (AML), often referred to as orphaned mine sites or legacy mine sites, contribute to how the mining industry is perceived, and the ongoing existence of these 'open sores' negatively contribute to the social licence to operate mines. Although it is difficult to quantify and classify AMLs, the impacts of AMLs in the United States are well publicised. The estimated number of AMLs in the United States varies widely, and can be categorised as sites covering prospecting pits, to adits and shafts, unreclaimed leaching facilities, tailings dams, waste rock piles and plant sites.

Current federal legislation in the United States to address AML reclamation is limited to coal operations and does not include aggregate, mineral, and hardrock mines. This lack of legislation results in a wide variety of standards and government authorities overseeing and providing guidance for reclamation efforts, a lack of direction for reclamation projects; and inadequate funding for reclamation efforts - ultimately resulting in little to no action to address the vast number of AMLs and the significant environmental and human health impacts created by those AMLs. Funding and actions for hardrock AMLs are typically addressed at the state level; however, these actions are focussed on public safety and the projects typically consist of securing structures, adits, and shafts. Although current coal-focussed AML remediation legislation has been successful, legislation directed at hardrock AML reclamation has been proposed for over 20 years at the federal level with no progress on establishment achieved to date.

Among current federal and state legislative initiatives being proposed to address hardrock AMLs in the United States is Good Samaritan legislation. Good Samaritan legislation seeks to encourage the partial or complete remediation of AMLs by providing appropriate protections for such Good Samaritans that voluntarily undertake in part or full AML remediation projects. The primary goal of Good Samaritan legislation is to ensure AML reclamation creates an "actual and significant" environmental benefit and provides an efficient and effective process to manage reclamation projects. In the current lacking state of hardrock AML legislation and actions, Good Samaritan legislation may be a creative and effective solution for addressing AML issues in the United States and as a result improve the legacy public perception of the mining industry resulting in improving the ability to obtain social license to operate.

\section{$2 \quad$ Mining Legacy in the United States}

Human beings have been mining metal and stone since prehistoric times for the manufacture of tools and weapons including flint, copper and gold, minerals for pigments and ceramics, and stone for tools and structures. There is evidence of prehistoric copper, gold, silver, and turquoise mining in North America dating back to 700 A.D. in the Southwest United States and the Great Lakes region (Drover \& Leonard, 1980), and mining has been integral in the development of our civilization globally and in the United States. The resources produced by mining influence nearly every facet of our society, from infrastructure driven by aggregates, steel, and base metals, to electronics and power production driven by precious metals, base metals, and rare earth metals, and to agriculture driven by minerals such as phosphorus.

The negative legacy of mining in the United States is as evident and earned as the positive legacy and consists of a long history of damage to the environment and human health. Significant and long-lasting impacts to the environment include groundwater and surface water contamination, dam failures, and irreversible changes to the landscape. Risks to human health and safety are significant as well including mine waste stability issues, open adits and shafts, and environmental contamination. All these risks are directly associated with AMLs. 


\subsection{Impacts to the Future of Mining}

According to Ernst and Young (Mitchell et al, 2020), the number one risk to the mining industry globally in 2021, which is the same as it was in 2019 and 2020, is the license to operate - depicted in Figure 1 . This is due to several factors, but the driving factor is the negative image of the mining industry as a result of the industry's negative legacy and AMLs. Paul Mitchell, Ernst and Young Global Mining \& Metal Leader stated, "License to operate is now impacted by increased expectations of all mining stakeholders, including investors and consumers. In today's climate, increased social pressure could result in a complete loss of license, so a clear branding strategy is required to address shifting societal expectations. Perceptions of the sector as being old-fashioned and dirty need to be challenged, and so building a social bond is make-or-break. Miners need to be part of the solution, not the problem, by engaging with topics including the circular economy and green mining of the future."

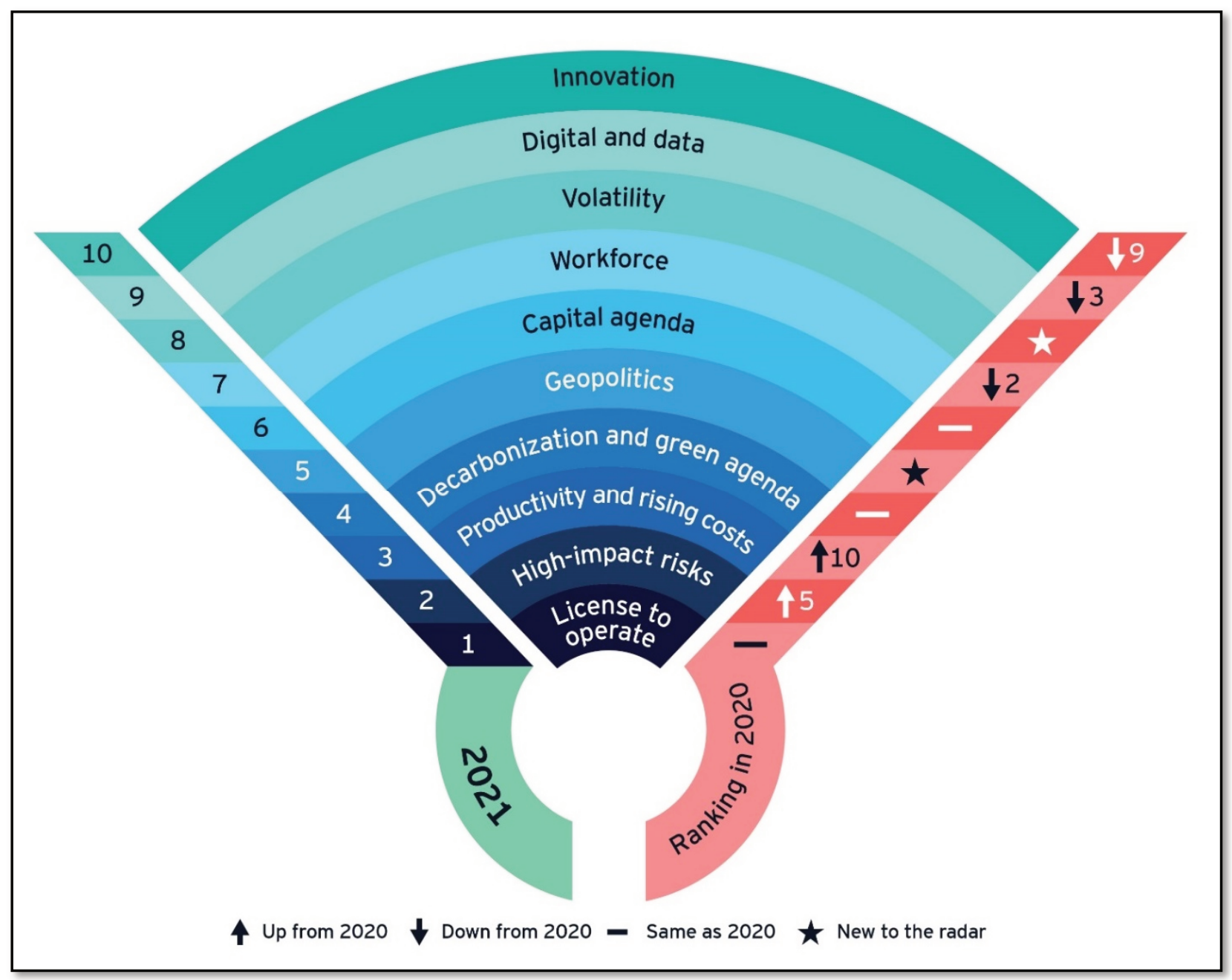

\section{Figure 1 Top 10 Business Risks Facing Mining and Metals in 2021 (Mitchell et al, 2021)}

The reclamation of AMLs in the United States and the associated reduction of risk to the environment and human health will be critical to improving the negative legacy of mining. Unfortunately, current regulatory programs in the United States are not well-suited for allowing Good Samaritans like non-profit organizations, private citizens, and most importantly the mining industry to improve environmental quality at hardrock AMLs. Generally, these regulatory programs require identification of a responsible party who assumes complete liability and is required to remediate a site to strict prescriptive environmental standards based on pre-disturbance conditions, which are often assumed. The intent of Good Samaritan legislation is to modify a current regulatory program or create a regulatory program allowing a party to improve environmental conditions (not necessarily restore them) without incurring future liability consequently. 


\section{$3 \quad$ Abandoned Mine Lands in the United States}

AMLs in the United States are defined as lands, waters, and surrounding watersheds where extraction, beneficiation or processing of ores and minerals have occurred on public land such as United States Forest Service (USFS), National Park Service (NPS), Bureau of Land Management (BLM), state, or tribal lands. AMLs contain features associated with mining and milling and range from simple prospect test pits to open adits and shafts to large scale plant sites, tailings storage facilities, and heap leach facilities. For the purposes of this paper, orphaned or legacy mine lands located on private property are not addressed - considering that the site is privately held (a party is liable), the site is not considered abandoned. This paper also is focussed on hardrock AMLs because there is a federal program that has been in place since 1977 that provides both direction and funding for the reclamation of coal AMLs.

\subsection{Identifying and Classifying Abandoned Mine Lands}

There have been numerous efforts over the past two decades to identify, classify, and quantify hardrock AMLs in the United States. These efforts have resulted in a wide range of results; therefore, this paper presents the most accepted quantification and classification, which was conducted by the Bureau of Land Management (BLM) in 2017. Roughly $28 \%$ of the United States is federally managed land and the BLM manages roughly $38 \%$ of those lands. The United States Forest Service (USFS) manages roughly $30 \%$, followed by the Fish and Wildlife Service (FWS) and the National Park Service (NPS). State and tribally managed public lands make up an additional $10 \%$ of lands in the United States.

The BLM has been conducting inventories of hardrock AMLs for decades and the latest results were posted January 2017. The inventory is limited to hardrock AMLs occurring on BLM managed lands and identified over 52,000 sites containing over 97,600 mining features, primarily occurring in the western United States and Alaska (Figure 2). Features include adits, declines, drill holes, heap leach facilities, open pits, inclines, mineral process sites, prospect pits, repository, other processing waste, shafts, stopes, buildings, tailings, and waste rock dumps. The most prominent features are open adits $(20 \%)$, open shafts $(21 \%)$, other $(19 \%)$, and waste rock dumps $(13 \%)$. Less prominent features are open pits $(9 \%)$, tailings $(0.5 \%)$, and heap leach facilities $(<0.1 \%)$.

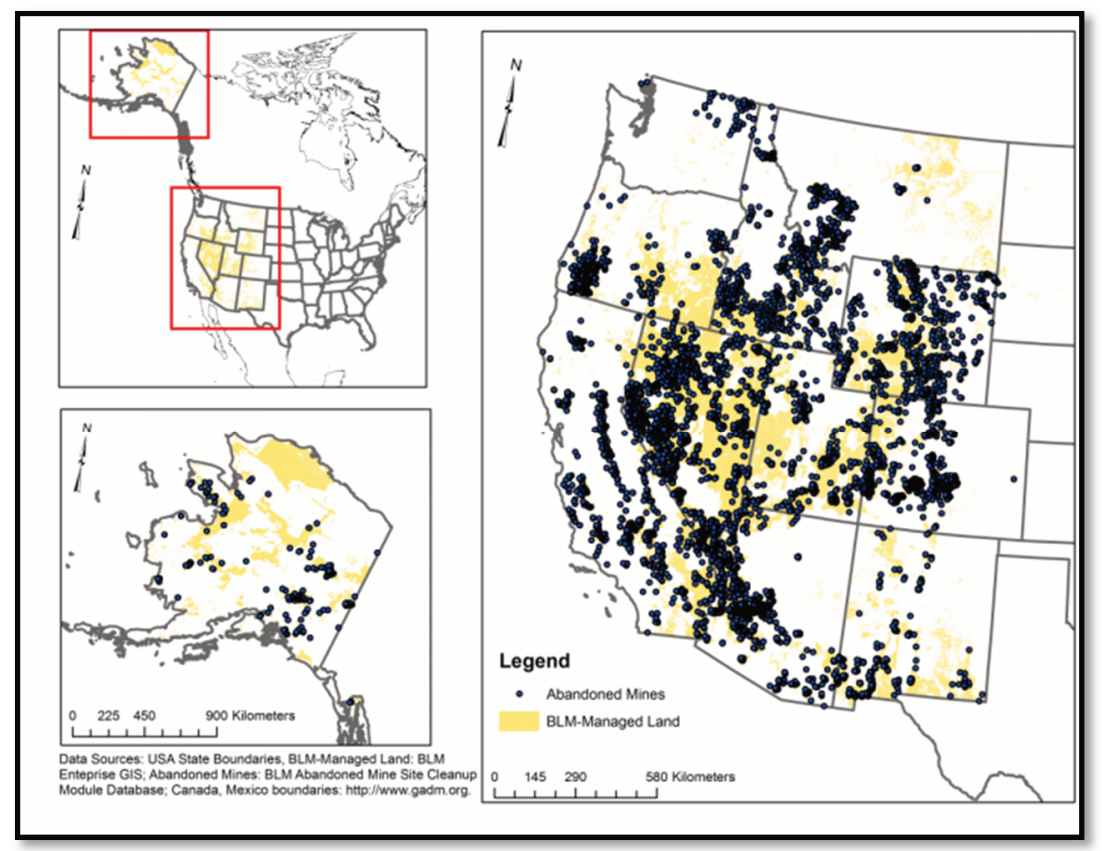

Figure 2 Concentration of Abandoned Mine Lands located on Bureau of Land Management Lands (https://www.blm.gov/programs/public-safety-and-fire/abandoned-mine-lands/blm-amlinventory 
The BLM manages roughly $38 \%$ of the federal lands in the United States and if we take the statistics from the BLM 2017 inventory and apply them to the remaining 62\% percent of federally-managed land, the total estimated number of hardrock AML sites is approximately 140,000 . If we apply the same factor to public and tribal lands the total number of hardrock AML sites on public land is approximately 185,000 . There are estimates as high as 500,000 hardrock AML sites located on public lands in the United States.

Classifying hardrock AMLs poses another significant challenge due to accessibility, human health risks, and funding. Hardrock AMLs were classified as part of the 2017 BLM inventory into seven categories ranging from "needs analysis" to "action completed" (Figure 3). Approximately $80 \%$ of the sites identified have not been studied and of the roughly 12,000 remaining sites that have been studied, just about half have either undergone reclamation or require no action. The investigation and classification of AMLs is challenging and costly. With no guidance or funding, it is likely that the pace of AML remediation need investigation and subsequent action will remain slow.

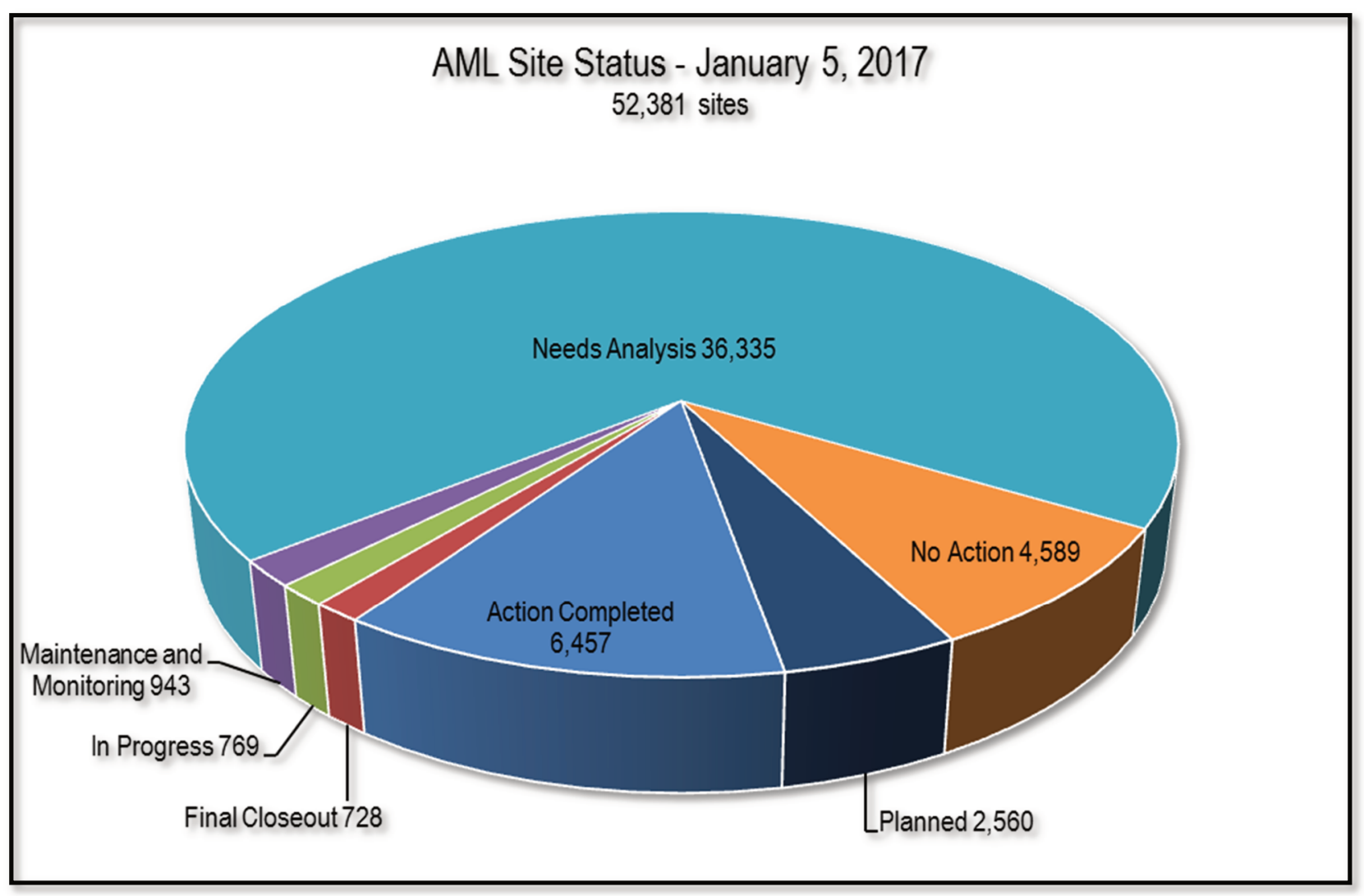

Figure 3 Status of Abandoned Mine Lands located on Bureau of Land Management and National Park Service Lands (https://www.blm.gov/programs/public-safety-and-fire/abandoned-minelands/blm-aml-inventory)

The results of inventory efforts to date indicate that:

1. Likely less than half of hardrock AMLs on BLM and NPS lands in the United States have been identified;

2. Most sites are open adits and shafts, and waste rock piles which typically have surface water pollution impacts and pose safety risks due to accessibility; and

3. The vast majority of hardrock AMLs in the United States pose unknown risks to the environment and safety, but considering the known breakdown of sites, the most prevalent risks are to surface water and human health. 
The estimated cost for the reclamation of hardrock AML sites varies widely due to the lack of understanding the quantity and the risks posed but is estimated to range from USD 35 billion to 75 billion. This estimate represents a significant investment even if fees were levied against operating mines or federal and state taxes were in place but considering there is no means of funding hardrock AML reclamation currently in place, the objective of reclaiming these AMLs is unachievable.

\section{$4 \quad$ Current Regulation and Independent Initiatives}

Currently in the United States there are no federal programs or legislation designed specifically to address the reclamation of hardrock AML sites. That is not to say hardrock AML reclamation has not and is not occurring, but rather the authority, direction, and funding of these projects varies widely between federal, state, and tribal agencies. AML reclamation projects are primarily conducted under the Comprehensive Environmental Response, Compensation, and Liability Act (CERCLA) and are funded on a "polluter pays" principal basis. There have been and continue to be federally funded hardrock AML reclamation projects, but these are few and conducted on a case-by-case basis based on relevant lead regulatory agency's priority ranking systems, which also varies by agency and region. There is federal legislation for coal AML remediation called the Surface Mining Control and Reclamation Act (SMCRA) that has been in place for over 40 years and has proven quite successful for addressing coal AMLs.

\subsection{Surface Mining Control and Reclamation Act}

The SMCRA is the primary federal law that regulates environmental impacts for coal mining operations in the United States. The act was passed into law in 1977 and was driven by the negative legacy of coal mining in the United States which consisted of long-term and significant environmental impacts that were going unchecked including current operations, and by the continued risk to human health that came with working in and living near coal mine operations. The SMCRA consists of five primary statutory obligations:

1. Establish environmental standards for coal mining operations during operation as well as postclosure;

2. Establish federal permitting requirements to ensure standards were being met;

3. Establish reclamation bonding requirements to ensure an operating mine was capable of meeting post-closure standards that also included funding for AMLs;

4. Establish the Office of Surface Mining Reclamation and Enforcement (OSMRE) to oversee the SMCRA; and

5. Create land restrictions for future coal mining including National Parks and designated wilderness areas.

The SMCRA provides the foundation for addressing coal AMLs through establishing an OSMRE as the lead agency assigning standards for AML reclamation, and providing funding through reclamation fees and donations. The OSMRE oversees enforcement of the SMCRA and coal AML reclamation on a federal level with AML site reclamation projects being executed at the state and tribal level. Federal standards for AML reclamation have been developed to meet federal environmental protection legislation requirements such as the Clean Water Act (CWA) as well as state regulations and agencies that are directly managing AML reclamation projects. Funding has been adequate and provided by several sources including reclamation fees paid by current operations.

The SMCRA has been very successful in generating funds to reclaim coal AMLs throughout the United States. Funding for SMCRA AML reclamation projects has been generated through multiple means:

- Reclamation fees levied on active coal mining operations;

- User charges imposed on or for land reclaimed pursuant to this title, after expenditures for maintenance have been deducted; 
- Donations by persons, corporations, associations, and foundations for the purposes of the title;

- Recovered moneys as provided for in the title; and

- Interest credited to the fund.

The fees levied on active coal operations is based on tons produced, the type of operation (surface, underground, lignite), and is a fee per ton produced, progressively reduced from 1978 to the present (Table 1).

As of September 2019, AML reclamation funding reached USD 11.496 billion of which nearly USD 6 billion has been granted to states and tribes for reclamation, over USD 1.5 billion has been committed to the United Mine Workers union health and retirement fund, over USD 1.75 billion has been spent on emergency projects and OSMRE operating expenses, and over USD 2 billion has yet to be appropriated (Table 2). The funding of coal AML reclamation through the SMCRA has been successful to the point that in very few cases, funding has been allocated to select hardrock AMLs through multiple states and tribes.

Table 1 Surface Mining Control and Reclamation Act Spending

\begin{tabular}{llll}
\hline Type of Operation & $\begin{array}{l}\text { 1978-2007 } \\
\text { Fee Rate } \\
\text { (c/ton) }\end{array}$ & $\begin{array}{l}\text { 2008-2012 } \\
\text { Fee Rate (c/ton) }\end{array}$ & $\begin{array}{l}\text { 2013-2021 } \\
\text { Fee Rate (c/ton) }\end{array}$ \\
\hline Surface Mine & $35 c$ & $31.5 c$ & $28 c$ \\
Underground Mine & $15 c$ & $313.5 c$ & $12 c$ \\
Lignite & $10 c$ & $9 c$ & $8 c$ \\
\hline
\end{tabular}

Table 2 Surface Mining Control and Reclamation Act Spending

\begin{tabular}{ll}
\hline Use of Funding & USD \\
\hline AML Grants to States and Tribes for Reclamation & $5,935 \mathrm{M}$ \\
United Mine Workers Association Health and Retirement Fund & $1,511 \mathrm{M}$ \\
OSMRE Operating Expenses and Emergency Projects & $1,816 \mathrm{M}$ \\
Unappropriated & $2,233 \mathrm{M}$ \\
\hline
\end{tabular}

Since its inception in 1977, the SMCRA has funded the reclamation of over 323,750 hectares including the closure of over 43,000 open adits and shafts, reclamation of 14,165 hectares of streams and wetlands, eliminated over 1,528 kilometres of highwalls, and abated over 3,700 dangerous water bodies. These projects have been completed or are currently being completed throughout the United States and have resulted in significant and long-term improvements to the environment and reduction of human health risks (Figure 4). 


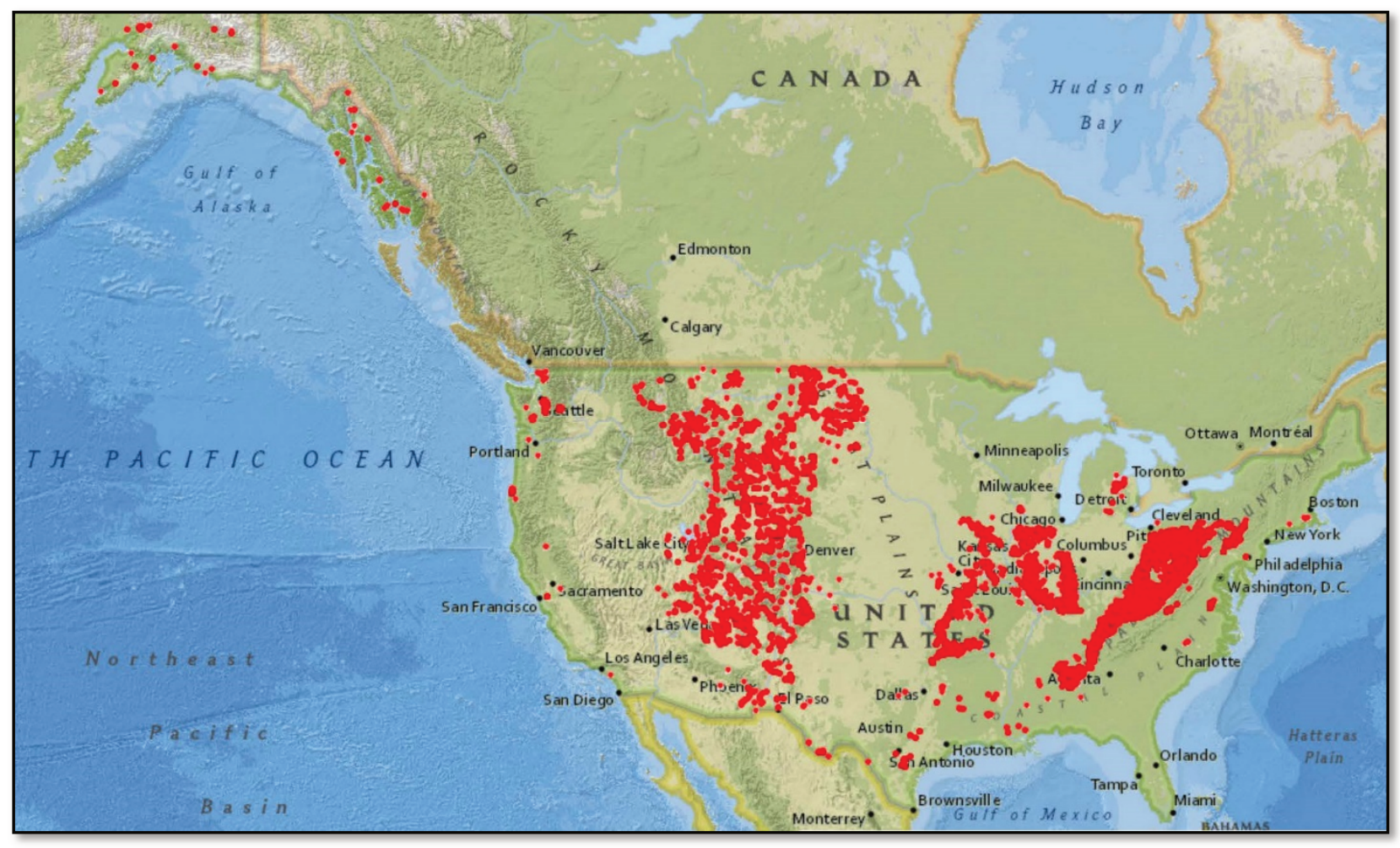

Figure 4 Surface Mining Control and Reclamation Act Completed Projects (OSMRE, 2021)

\subsection{State and Tribal Programs}

Nearly every state and tribe in the United States has a mine reclamation program. These programs were started following the passing of the SMCRA and were typically developed to administer coal AML reclamation projects. These programs evolved quickly to include mine health and safety, state mine environmental and reclamation requirements, and hardrock AML reclamation. Hardrock mine closure requirements are defined on a state and tribal level and there are often multiple state agencies with reclamation standards and bonding requirements. For example, in the state of Arizona, the Arizona Department of Environmental Quality has reclamation standards and bonding requirements for the environmental elements they have jurisdiction over which includes groundwater and surface water. The Arizona State Mine Inspector issues permits for mining operations in the state and has general reclamation standards and bonding requirements focussed primarily on human health (access) and aesthetics.

As it relates to hardrock AMLs, state and tribal programs lack funding and are focussed primarily on human health and restricting access to dangerous sites. The majority of work conducted for hardrock AML reclamation programs include closing open adits and shafts, fencing open pits or unstable mine waste facilities, and signage warning of dangerous conditions in historically active mining areas. Funding for hardrock AML site reclamation projects are typically through state taxes - however, state taxes are limited. Limited funding is also obtained through the SMCRA. These state and tribal AML reclamation programs were not developed to specifically address hardrock AMLs and although there has been success with protecting the public from dangerous sites, the multiple agencies overseeing these projects lead to an unclear definition of reclamation standards, an unclear view of authority over such projects, and limited progress especially related to addressing on and offsite environmental impacts. 


\subsection{Federal Programs}

There currently is no federal program or legislation to address hardrock AMLs in the United States; however, federal agencies are active in hardrock AML reclamation primarily conducted under the CERCLA and funded on a "polluter pays" principal basis. Federal agencies that have authority over hardrock AML reclamation include:

- United States Environmental Protection Agency (involved in all federal hardrock AML reclamation projects)

- Department of the Interior

○ Bureau of Land Management

- National Park Service

○ Office of Surface Mining Reclamation and Enforcement

- United States Geographic Survey

- Department of Agriculture

- United States Forest Service

- Natural Resources Conservation Services

- United States Army Corps of Engineers

- United States Department of Justice

Numerous hardrock AML reclamation projects have been and are actively being completed, often with multiple agencies working together with state and tribal agencies - however, the number of projects pales in comparison with coal AML reclamation projects. Approximately $10 \%$ of identified hardrock AML sites on BLM managed lands have been reclaimed as of 2017, far less than coal sites reclaimed under the SMCRA. Similar to state and tribal hardrock AML reclamation programs, the lack of consistent reclamation standards, multiple agencies with authority, and inadequate funding have led to a lack of progress reclaiming hardrock AML sites.

\subsection{Independent Programs}

Non-governmental Organizations (NGOs) have been actively pursuing and executing hardrock AML reclamation projects throughout the United States over the past 25 years, but their participation has been limited due to liability concerns. Trout Unlimited and Sierra Fund among a few others have been active NGOs to date. The hardrock AML reclamation projects that have been undertaken by these NGOs are also limited due to liability concerns, funding, and a misalignment with goals of the NGO membership. In numerous cases the mining industry has supported NGO-led hardrock AML reclamation projects, which has led to an unlikely pairing, considering the often-contentious relationship between the mining industry and NGOs. However, the projects have been quite successful and have made progress towards improving the negative legacy of the mining industry in the areas where the projects were completed.

\section{Good Samaritan Legislation}

Good Samaritan legislation aims to promote hardrock AML reclamation by protecting Good Samaritans that want to take on AML reclamation projects from liability, promoting "actual and significant benefits", and by creating a clear and consistent process to do so across the United States. This legislation, in general, is intended to address the lack of authority over hardrock AML reclamation, the lack of consistent reclamation standards, securing funding to identify and characterize sites, and to design and execute reclamation projects. 
One of the most impactful aspects of the Good Samaritan legislation is the protection of Good Samaritans from future liability. Without protection, an individual, NGO, or company taking on reclamation projects would also assume full and enduring liability for the site meeting federal and state standards immediately upon acting. This risk has prevented good Samaritans from conducting hardrock AML reclamation projects. The second most impactful aspect of Good Samaritan legislation, which is in direct response to the risk of long-term liability, is the goal of achieving "actual and significant environmental benefits" for these projects (either in part or in full). This approach is currently being taken at multiple hardrock AML reclamation projects being conducted under the CERCLA and reinforces that the goal is to realize significant environmental improvement from current conditions, which means a project may not meet state or tribal or federal standards for operating mines.

The Gold King mine is an example of this approach and is being managed by the United States Environmental Protection Agency (USEPA) and federally funded. This site is also an example of the challenges presented by hardrock AML reclamation in the United States and the significant risks that accompany reclamation activities without adequate investigation and funding.

\subsection{Recent Initiatives}

Formulating and revisions to Good Samaritan legislation has been a work in progress for over 20 years in the United States and continues to be actively pursued at the federal level with multiple acts currently being considered by the United States senate and house of representatives.

\subsubsection{Cleanup of Inactive and Abandoned Mines Act, 2006}

In 2006, Ken Salazar, Senator for the state of Colorado, sponsored Senate Bill 1848 (S. 1848) and introduced the Cleanup of Inactive and Abandoned Mines Act. S 1848 defined the purpose of the bill as follows (S. 1848, Section 2.b):

“(1) to encourage partial or complete remediation of inactive and abandoned mine sites for the public good by persons that are not otherwise legally responsible for the remediation;

(2) to provide appropriate protections for Good Samaritans under applicable environmental laws;

(3) to ensure that remediation performed by Good Samaritans creates actual and significant environmental benefits;

(4) to ensure that remediation by Good Samaritans is carried out

(A) with the approval and agreement, and in the discretion, of affected Federal, State, and local authorities and with review by the public; and

(B) in a manner that is beneficial to the environment and all affected communities;

(5) to create an efficient permit process under which the cost and complexity of obtaining a permit are commensurate with the scope of remediation work to be completed and the environmental benefits from the work;

(6) to avoid permitting for ongoing, for-profit businesses that specialize in multiple Good Samaritan projects that are designed to be permitted outside otherwise applicable Federal, State, and local environmental laws;

(7) to ensure that the protections for Good Samaritans provided in this Act are interpreted in accordance with the purposes of this Act and to enhance the public good; and

(8) to further innovation and cooperation among the Federal Government, State governments, private individuals, and corporations to accelerate conservation and environmental restoration."

S 1848 defined a federal process to reclaim hardrock AML sites throughout the United States, provided protection for Good Samaritans from long-term liability, but did not seek funding through additional taxes to the public or fees levied on active hardrock mining operations. Funding for these projects would be provided 
primarily by Good Samaritans including the mining industry, NGOs, and private citizens. As discussed earlier, there are currently hardrock AML reclamation projects being funded and executed with funds from the private sector and proponents of this bill feel there is adequate private funding to at least begin tackling the hardrock AML remediation issues. When considering that the estimated costs for reclaiming hardrock AMLs in the United States ranges from USD 35 billion to 75 billion, funding is a significant challenge, and this approach may not be entirely successful. However, when considering the importance of the mining industry improving the negative legacy of mining related to license to operate, the number one risk to the mining industry globally today, the interest to reclaim hardrock AMLs and the funding to do so may be prevalent from the mining industry along.

S 1848 was reviewed by the Senate Committee on Environmental and Public Works along with similar acts such as the Good Samaritan Clean Watershed Act (House Bill 5404) and was not enacted.

\subsubsection{Good Samaritan Remediation of Orphan Hardrock Mines Act of 2018}

In 2018, Scott Tipton, United States Representative of Colorado, and Cory Gardner, Senator for the state of Colorado, jointly sponsored and introduced the Good Samaritan Remediation of Orphan Mines Act House Bill 7226 (HR 7226) and S 3727. This bill, very similar to S 1848, was intended to promote the remediation of hardrock AMLs by establishing the authority as well as a permitting process at a federal level to manage projects to, protections for Good Samaritans executing the projects, and provide funding. HR 7226 differs from $\mathrm{S} 1848$ by proposing a pilot program of 15 projects to be funded by federal grants essentially making this bill a pilot program for hardrock AML reclamation that is solely federally funding. If proven successful HR 7726 would be followed by long-term legislation that would likely be open to alternative funding options, similar to the SMCRA.

HR 7226 and S 3727 were reviewed by the Senate Committee on Environmental and Public Works and the following Congressional Subcommittees: Energy and Mineral Resources, Water Resources and Environment, Transpiration and Infrastructure, Energy and Commerce, and Natural Resources. Both HR 7226 an SB 3727 were not enacted.

\subsection{Pennsylvania Environmental Good Samaritan Act, 1999}

The state of Pennsylvania has a long history of mining, primarily coal, and as a result negative long-term environmental impacts remain throughout the state. In 1999, the Environmental Good Samaritan Act was signed into law along with another environmental initiative. This act was intended to provide funding for AML reclamation as well as abandoned oil and gas wells located on public and private property and was focussed on reducing water pollution. Funding was provided totalling USD 1.3 billion and protections for Good Samaritans was provided at the state level; however, protection from federal environmental regulations was not provided. As of 2020, 103 projects have been approved of which 76 are currently active in various states of investigation, reclamation, or monitoring, one project was currently waiting for approval and funding, and 25 projects have been completed (Figure 5). All these projects are mine related and range from streambank and riparian area reclamation and improvements to passive water treatment for acid rock drainage. The Pennsylvania Environmental Good Samaritan Act is an example of Good Samaritan legislation in action and the improvements to the environmental, human health, and legacy of the mining industry that can occur as a result of such legislation. 


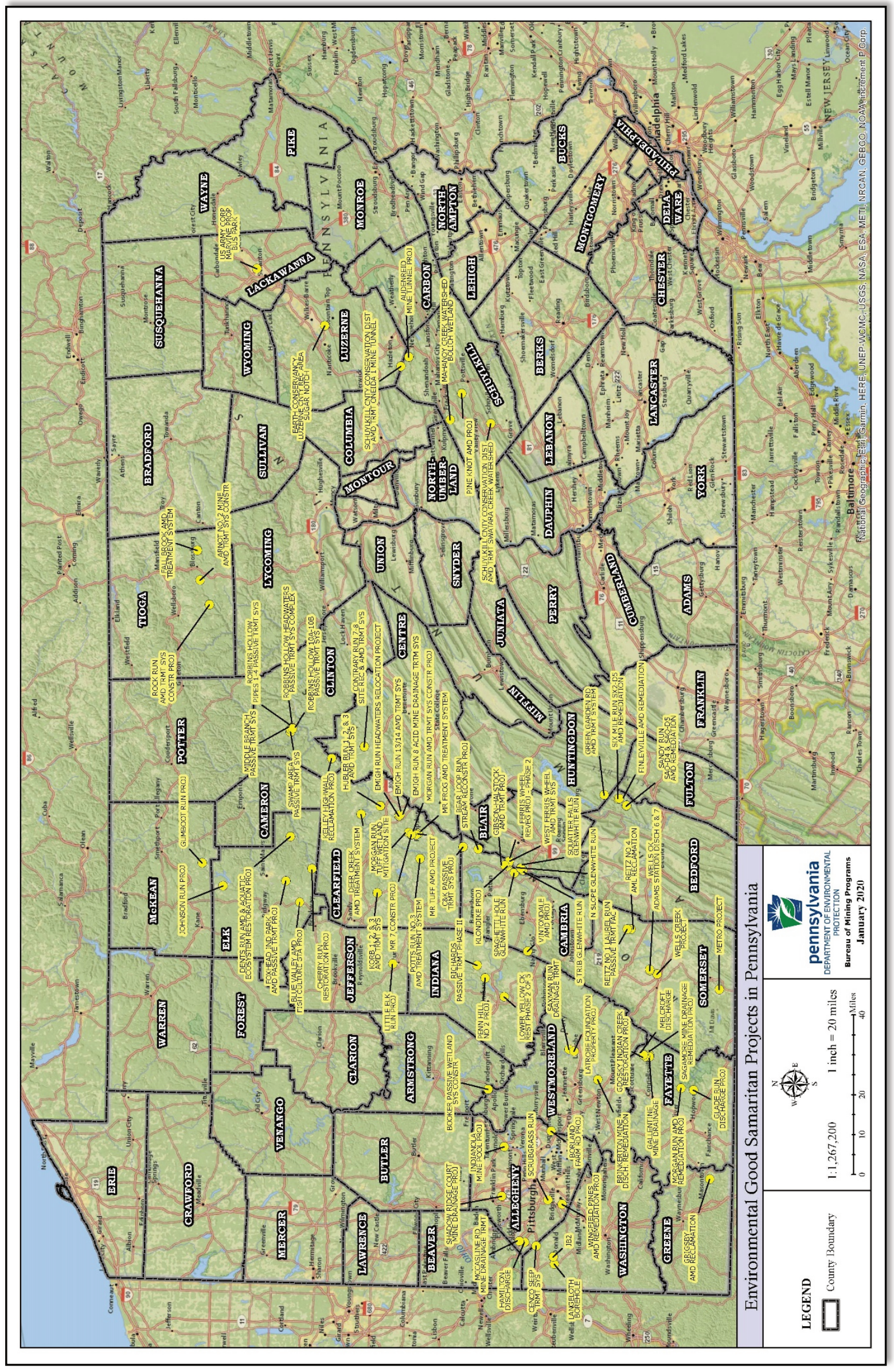

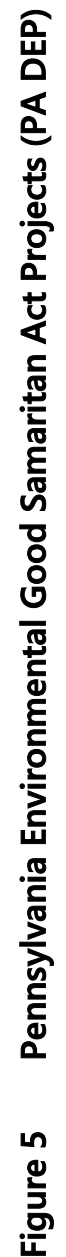




\section{Conclusion}

The estimated number of hardrock AMLs throughout the United States (approximately 185,000) and costs for reclamation (USD 35 - 75 billion) are an ever-present reminder of the negative legacy the mining industry has in the United States and pose a significant challenge to the mining industry's future. The SMCRA has been successful in legislating and supporting coal AML reclamation, effectively reducing environmental impacts and risk to human health since 1978. Hardrock AML reclamation however still lacks federal and state legislation to stimulate and allow for similar successes and as a result associated long-term environmental impacts and risks to human health will likely remain prevalent.

Good Samaritan legislation in the United States, and perhaps globally, may present a viable public-private opportunity to improve the negative legacy of the mining industry, its public image, and ultimately improve the ability to obtain social license to operate and ensure a strong future for the mining industry. However, Good Samaritan legislation for hardrock AML reclamation currently does not exist on a federal level and political attempts over the past two decades to establish a federal program have not been successful.

The mining industry and key stakeholders involved directly or indirectly in the mining community, can shape legislation and the approach to hardrock AML reclamation to achieve their goals of improved environmental conditions, reduced risks to human health, and improved ability obtain social license to operate. We as the mining industry have the opportunity to shape our legacy, to make positive changes to the environment, to benefit stakeholders, and to reduce the risk and challenge of obtaining our social license to operate and as a result continue to provide the world with resources through adequate good Samaritan legislation.

\section{References}

Drover, C, Leonard, N 1980, 'Prehistoric Turquoise Mining in the Halloran Springs District, San Bernardino County, California', Journal of California and Great Basin Anthropology, vol. 2, pp. 245-256.

Good Samaritan Remediation of Orphan Hardrock Mines Act of 2018, H.R. 7226, 115th Congress 2018, https://www.congress.gov/bill/115th-congress/housebill/7226?q=\%7B\%22search\%22\%3A\%5B\%22Bill+7226\%22\%5D\%7D\&s=2\&r=3

Good Samaritan Remediation of Orphan Hardrock Mines Act of 2018, S. 3727,115th Congress 2018, https://www.congress.gov/bill/115th-congress/senate-bill/3727

Mitchell, P, Stall, R, \& Van Dinter A 2020, Top 10 Business Risk and Opportunities - 2021, EY, viewed 13 February 2021 , https://www.ey.com/en_gl/mining-metals/top-10-business-risks-and-opportunities-for-mining-and-metals-in-2021

Office of Surface Mining Reclamation and Enforcement U.S. Department of the Interior, eAmlis Map, OSMRE, viewed 02 February 2021, https://amlis.osmre.gov/Map.aspx

Pennsylvania Department of Environmental Protection, Environmental Good Samaritan Act, DEP PA, viewed 14 December 2020 , https://www.dep.pa.gov/Business/Land/Mining/BureauofMiningPrograms/Pages/GoodSamaritanAct.aspx

U.S. Department of the Interior, Bureau of Land Management, AML Inventory, viewed 14 December 2020, https://www.blm.gov/programs/public-safety-and-fire/abandoned-mine-lands/blm-aml-inventory

U.S. Department of the Interior, Natural Resources Revenue Data, Abandoned Mine Land Reclamation Program, viewed 02 February 2021, https://revenuedata.doi.gov/how-revenue-works/aml-reclamation-program/ 